\title{
IMPLEMENTASI METODE BELAJAR PEER TEACHING UNTUK MENINGKATKAN KEAKTIFAN SISWA DAN HASIL BELAJAR
}

\author{
Oleh : \\ Dian Paramita Candra Astika ${ }^{1}$ \\ Isroah $^{2}$
}

\begin{abstract}
Abstrak
Penelitian ini bertujuan untuk meningkatkan keaktifan siswa dan hasil belajar siswa yang terdiri dari hasil belajar ranah kognitif, ranah afektif dan ranah pada Kompetensi Dasar Menyusun Laporan Keuangan Perusahaan Jasa Siswa Kelas X Ak 2 Kompetensi Keahlian Akuntansi di SMK Negeri 1 Yogyakarta Tahun Ajaran 2012/2013 setelah diterapkannya Metode Belajar Peer Teaching.

Penelitian ini merupakan jenis penelitian tindakan kelas, pada proses pembelajarannya menerapkan metode belajar peer teaching. PTK ada 4 tahapan yang dilakukan yaitu planning, acting, observing dan reflecting. Sasaran penelitian ini adalah siswa kelas X Ak.2 SMK Negeri 1 Yogyakarta dengan jumlah 35 siswa. Sistematika pelaksanaan penelitian ini menerapkan 2 siklus. Aspek yang diteliti meliputi keaktifan siswa dan hasil belajar. Keaktifan siswa diamati dengan lembar observasi yang mencakup beberapa aspek yang diamati dengan menggunakan rating scale. Hasil belajar ranah kognitif diukur dengan melaksanakan pretest pada awal pertemuan dan mengadakan posttest pada akhir pertemuan. Hasil belajar ranah afektif dan psikomotor diukur dengan hasil pengamatan yang dilakukan observer yang terdiri dari beberapa aspek yang diamati. Data dianalisis melalui tahapan reduksi, paparan data dan penyimpulan hasil.

Hasil penelitian menunjukkan: (1) peningkatan rata-rata keaktifan siswa mengalami peningkatan sebesar $20,73 \%$ yaitu pada siklus 1 mencapai $67,79 \%$ menjadi 88,52\% pada siklus 2, (2) hasil belajar ranah kognitif yang diperoleh siswa mengalami peningkatan dari siklus 1 ke siklus 2, ketuntasan belajar pada pretest siklus 1 yang mencapai KKM 70 sebanyak 32,35\%, pada posttest siklus 1 mencapai 91,18\%, sedangkan ketuntasan belajar pada pretest siklus 2 adalah $47,22 \%$, pada posttest siklus 2 ketuntasan belajar mencapai 100\%, (3) persentase hasil belajar ranah afektif mengalami peningkatan rata-rata sebesar $10,50 \%$ dari siklus $177,41 \%$ menjadi $87,91 \%$ pada siklus 2 , (4) persentase peningkatan ratarata hasil belajar ranah psikomotor sebesar $24,51 \%$ yaitu dari siklus $160,78 \%$ meningkat pada siklus 2 menjadi 85,29\%.
\end{abstract}

Kata Kunci: Keaktifan Siswa, Hasil Belajar, Metode Belajar Peer Teaching

\footnotetext{
${ }^{1}$ Alumni Prodi Pendidikan Akuntansi Fakultas Ekonomi Universitas Negeri Yogyakarta

2 Staf Pengajar Jurusan P. Akuntansi Fakultas Ekononi Universitas Negeri Yogyakarta
} 


\section{Abstract}

This research aims to increase student activity and student learning outcomes consisting of cognitive learning outcomes, and the affective domain of the Basic Competency Compile Financial Services Company Grade X Ak 2 Accounting Skills Competency in SMK Negeri 1 Yogyakarta in Academic Year 2012/2013 after implementation of Peer Teaching Learning Methods.

This research is a classroom action research, the process of learning to apply peer teaching learning methods. PTK there are 4 stages that do the planning, acting, observing and reflecting. Objectives of this study were students of class X Ak.2 SMK Negeri 1 Yogyakarta by the number of 35 students. Systematics of research is to apply the 2 cycles. Aspects studied include student activity and learning outcomes. Student activity observed with the observation sheet that covers some aspects observed by using a rating scale. Cognitive learning outcomes measured by conducting a pretest at the beginning of the meeting and held a posttest at the end of the meeting. The results of the affective and psychomotor learning is measured by the results of the observations made observer that consists of several aspects of the observed. Data were analyzed through the stages of reduction, exposure data and inference results.

The results showed: (1) an increase in the average activity of students has increased by $20.73 \%$ ie in cycle 1 has $67.79 \%$ to $88.52 \%$ in cycle 2, (2) cognitive learning outcomes obtained by students has increased from cycle 1 to cycle 2, mastery learning on the pretest cycle 1 that reached as much as $32.35 \%$ KKM 70, at posttest Cycle 1 reached $91.18 \%$, while mastery learning on the pretest cycle 2 was $47.22 \%$, the posttest cycle 2 reach $100 \%$ mastery learning, (3) the percentage of the affective learning outcomes has increased an average of $10.50 \%$ of cycle 1 $77.41 \%$ to $87.91 \%$ in cycle 2, (4) the percentage increase in average learning outcomes psychomotor domains of $24.51 \%$ from $60.78 \%$ one cycle increase in cycle 2 to $85.29 \%$.

Key Words: Student Activity, Student Learning Outcomes, Peer Teaching Learning Methods.

\section{A. Pendahuluan}

Pendidikan memegang peranan penting untuk menjamin kelangsungan hidup bangsa dan negara. Pendidikan sebagai wadah untuk meningkatkan dan mengembangkan kualitas sumber daya manusia (SDM). Sumber daya yang berkualitas dapat membawa kemajuan IPTEK. Kualitas SDM dapat ditingkatkan dengan cara meningkatkan kualitas pendidikan.

Mempersiapkan lulusan SMK yang siap kerja dari seluruh lulusan SMK di Indonesia perlu adanya penyamaan kualitas lulusan SMK dari berbagai daerah. Hal tersebut dilakukan dengan pembuatan standardisasi minimal kelulusan. Jika nilai yang dicapai tidak memenuhi standar minimal maka siswa diwajibkan melakukan perbaikan atau mengulangi kompentensi yang diberikan. Hasil Belajar siswa berbeda antara kompentensi satu dengan yang lain dan berbeda juga antara satu siswa dengan siswa yang lain. 
Proses pembelajaran akuntansi SMK Negeri 1 Yogyakarta selama ini cenderung masih dilakukan dengan metode belajar konvensional, yaitu motode ceramah. Pembelajaran dengan motode ceramah yaitu proses pembelajaran yang dimulai dengan penjelasan materi pelajaran oleh guru berkaitan dengan konsep, contoh soal, dan latihan soal yang dikerjakan oleh siswa. Siswa diberi kesempatan untuk bertanya setelah penyajian materi oleh guru atau sebelum guru melanjutkan penjelasan materi berikutnya.

Berdasarkan hasil pengamatan yang dilakukan di X AK 2 SMK N 1 Yogyakarta pada hari Rabu 17 Oktober 2012, selama proses pembelajaran suasana kelas terkesan belum kondusif, siswa cenderung ramai dan suka bercanda dengan temannya sendiri, sehingga siswa kurang aktif dan kurang perduli dengan pembelajaran di kelas. Pembelajaran di kelas X AK 2 dengan pelajaran siklus akuntansi masih banyak siswa yang belum memenuhi kriteria ketuntasan minimal (KKM) yakni 70. Hal ini terlihat dari hasil ujian harian pertama pada Kompentensi Dasar Memahami Dasar-Dasar Akuntansi dan Mencatat Transaksi ke dalam Persamaan Dasar Akuntansi di mana jumlah siswa yang tidak lulus atau yang belum memenuhi KKM sebanyak $53 \%$ atau 19 dari 36 siswa, sehingga siswa harus mengikuti ujian perbaikan. Salah satu alternatif yang dapat digunakan sebagai usaha meningkatkan keaktifan siswa dan hasil belajar akuntansi siswa adalah dengan metode belajar peer teaching.

Metode belajar peer teaching adalah metode belajar yang memanfaatkan teman sebaya sebagai tutor dalam proses belajar dan mengajar. Boud, Cohen dan Sampson's (Endang Mulyatiningsih, 2001: 249) menjelaskan bahwa apabila peer teaching menjadi bagian dari proses pembelajaran di sekolah, siswa yang menjadi guru dapat menunjukkan berbagai peran seperti: pure teacher, mediator, work partner, dan role model.

Berdasarkan uraian diatas, peneliti melakukan penelitian dengan judul "Implementasi Metode Belajar Peer Teaching untuk Meningkatkan Keaktifan Siswa dan Hasil Belajar Pada Kompetensi Dasar Menyusun Laporan Keuangan Perusahaan Jasa Siswa Kelas X Ak 2 Kompetensi Keahlian Akuntansi SMK Negeri 1 Yogyakarta Tahun Ajaran 2012/2013”.

\section{Keaktifan Belajar Siswa}

Menurut Rochman Natawijaya (Depdiknas 2003: 31) belajar aktif adalah suatu sistem belajar mengajar yang menekankan keaktifan siswa secara fisik, mental intelektual dan emosional guna memperoleh hasil belajar yang berupa perpaduan antara aspek kognitif, afektif dan psikomotor. Keaktifan yang dimaksud dalam penelitian ini adalah sebuah kegiatan. Keaktifan siswa adalah kegiatan yang dilakukan oleh siswa yang dapat membawa perubahan ke arah yang lebih baik pada diri siswa karena adanya interaksi antara individu dengan individu dan individu dengan lingkungan.

\section{Hasil Belajar}

Hasil belajar merupakan hal yang dipandang dari dua sisi yaitu sisi siswa dan sisi guru (Dimyati dan Mudjiono, 2006: 250). Dari sisi siswa, hasil belajar merupakan tingkat perkembangan mental yang lebih baik bila dibandingkan pada saat sebelum belajar. Tingkat perkembangan mental tersebut terwujud pada jenis-jenis ranah kognitif, afektif dan psikomotor, 
sedangkan dari sisi guru, hasil belajar merupakan saat diselesaikannya bahan pelajaran.

\section{Metode Belajar Peer Teaching}

Metode belajar peer teaching adalah metode belajar yang memanfaatkan teman sebaya sebagai tutor dalam proses belajar dan mengajar. Boud, Cohen dan Sampson's sebagaimana dikutip oleh Endang Mulyatiningsih (2001: 249) menjelaskan bahwa apabila peer teaching menjadi bagian dari proses pembelajaran di sekolah, peserta didik yang menjadi guru dapat menunjukan berbagai peran seperti: pure teacher, mediatoer, work patner, dan role model.

\section{B. Metode Penelitian}

\section{Tempat dan Waktu Penelitian}

Penelitian Tindakan Kelas ini dilaksanakan di kelas X Ak. 2 SMK N 1 Yogyakarta yang beralamat di Jalan Kemetiran Kidul Nomor 35, Yogyakarta. Pelaksanaan penelitian tindakan kelas pada bulan OktoberNovember 2012.

\section{Jenis Penelitian}

Jenis Penelitian ini adalah Penelitian Tindakan Kelas yang melalui empat tahapan yaitu, perencanaan, pelaksanaan, pengamatan dan refleksi. Penelitian ini merupakan Penelitian Tindakan Kelas dalam bentuk kolaborasi dan partisipasi.

\section{Subjek dan Objek Penelitian}

Subjek dalam penelitian ini adalah siswa kelas X Ak 2 Kompetensi Keahlian Akuntansi SMK N 1 Yogyakarta Tahun Ajaran 2012/2013 yang sekarang terdiri dari 35 siswa, sedangkan yang menjadi objek penelitian adalah pelaksanaan pembelajaran dengan metode belajar Peer Teaching untuk meningkatkan Keaktifan Siswa dan Hasil Belajar pada pokok bahasan Menyusun Laporan Keuangan Pada Perusahaan Jasa siswa Kelas X Kompetensi Keahlia Akuntansi SMK Negeri 1 Yogyakarta.

\section{Teknik Pengumpulan Data}

a) Observasi

Observasi yang akan dilakukan oleh peneliti merupakan observasi partisipatif.

b) Tes Hasil Belajar

Tes sebagai alat penilaian adalah pertanyaan-pertanyaan yang diberikan kepada siswa untuk mendapatkan jawaban dari siswa dalam bentuk lisan, tulisan atau dalam bentuk perbuatan (tes tindakan). Catatan Lapangan

c) Dokumentasi

Dokumentasi dilakukan dengan mencari data berupa catatan maupun dokumen tertulis lainnya. Dalam penelitian ini dokumen yang akan digunakan adalah catatan lapangan untuk mencatat kejadian selama pembelajaran 


\section{Instrumen Penelitian}

a) Lembar Observasi

Lembar observasi digunakan sebagai pedoman untuk melakukan pengamatan yang ditujukan untuk mendapatkan data yang ingin diketahui oleh peneliti. Lembar observasi ini diisi dengan memberikan skor pada tiap indikator yang telah dilakukan siswa berdasarkan frekuensi kemunculannya.

Tabel 1. Pedoman Penilaian Aspek Keaktifan Siswa

\begin{tabular}{|l|l|c|}
\hline No & \multicolumn{1}{|c|}{ Aspek keaktifan siswa yang dinilai } & Sumber Data \\
\hline 1 & Mencatat materi akuntansi & Siswa \\
\hline 2 & Membuat rencana belajar & Siswa \\
\hline 3 & $\begin{array}{l}\text { Membantu kesulitan teman sekelompok } \\
\text { dalam menguasai materi pelajaran }\end{array}$ & Siswa \\
\hline 4 & Mengemukakan pendapat dalam diskusi & Siswa \\
\hline 5 & Mempresentasikan hasil diskusi & Siswa \\
\hline 6 & $\begin{array}{l}\text { Siswa bertanya saat pembelajaran maupun } \\
\text { diskusi tentang materi }\end{array}$ & Siswa \\
\hline 7 & $\begin{array}{l}\text { Siswa menjawab pertanyaan yang diberikan } \\
\text { guru maupun teman saat diskusi }\end{array}$ & Siswa \\
\hline 8 & Mengerjakan tugas akuntansi & Siswa \\
\hline 9 & Berpartisipasi dalam tugas kelompok & Siswa \\
\hline 10 & $\begin{array}{l}\text { Memberikan kesimpulan di akhir } \\
\text { pertemuan }\end{array}$ & Siswa \\
\hline
\end{tabular}

Tabel 2. Alternatif Penilaian dalam lembar Observasi

\begin{tabular}{|l|l|}
\hline Aktif & 2 \\
\hline Cukup aktif & 1 \\
\hline Tidak aktif & 0 \\
\hline
\end{tabular}

b) Tes

1) Penilaian Ranah Kognitif

Penilaian ranah kognitif dilakukan dengan cara melakukan tes pada awal dan akhir siklus. Tes berupa pendalaman materi yang sedang dibahas.

2) Penilaian Ranah Afektif

Penilaian ranah afektif dilakukan dengan cara pengamatan kepada siswa pada setiap siklus. Adapun pengamatan dilakukan sebagai berikut: 
Jurnal Pendidikan Akuntansi Indonesia, Vol. XI, No. 1, Tahun 2013

Dian Paramita Candra Astika \& Isroah

Halaman $29-49$

Tabel 3. Pedoman Penilaian Hasil Belajar Ranah Afektif

\begin{tabular}{|l|l|l|}
\hline Aspek Penilaian & Skor & Kriteria Penilaian \\
\hline 1. Berpakaian rapi sesuai & $80-100$ (A) & Baik Sekali \\
dengan ketentuan sekolah & $66-79$ (B) & Baik \\
& $56-65$ (C) & Cukup \\
& $40-55$ (D) & Kurang \\
& $30-39$ (E) & Sangat Kurang \\
\hline 2. Datang sekolah tepat & $80-100$ (A) & Baik Sekali \\
waktu & $66-79$ (B) & Baik \\
& $56-65$ (C) & Cukup \\
& $40-55$ (D) & Kurang \\
& $30-39$ (E)) & Sangat Kurang \\
\hline 3. Memberikan saran dalam & $80-100$ (A) & Baik Sekali \\
diskusi dengan sopan & $66-79$ (B) & Baik \\
& $56-65$ (C) & Cukup \\
& $40-55$ (D) & Kurang \\
& $30-39$ (E) $)$ & Sangat Kurang \\
\hline 4. Membawa peralatan dan & $80-100$ (A) & Baik Sekali \\
kelengkapan belajar yang & $66-79$ (B) & Baik \\
ditugaskan guru & $56-65$ (C) & Cukup \\
& $40-55$ (D) & Kurang \\
& $30-39$ (E) $)$ & Sangat Kurang \\
\hline 5. Mengumpulkan semua & $80-100$ (A) & Baik Sekali \\
tugas yang diberikan tepat & $66-79$ (B) & Baik \\
waktu & $56-65$ (C) & Cukup \\
& $40-55$ (D) & Kurang \\
& $30-39$ (E) $)$ & Sangat Kurang \\
\hline
\end{tabular}

3) Penilaian Ranah Psikomotor

Penilaian secara psikomotor dilakukan dengan cara pengamatan dalam mengerjakan soal yang diberikan kepada siswa pada setiap siklus. Adapun pengamatan yang dilakukan sebagai berikut:

Tabel 4. Pedoman Penilaian Hasil Belajar Ranah Psikomotor

\begin{tabular}{|c|c|c|c|}
\hline Aspek Penilaian & Kriteria Penilaian & Skor & Keterangan \\
\hline $\begin{array}{l}\text { 1. Respon jika } \\
\text { diberi } \\
\text { pertanyaan }\end{array}$ & $\begin{array}{l}\text { - Langsung menjawab dan } \\
\text { jawaban benar } \\
\text { - Langsung menjawab tapi } \\
\text { jawaban kurang tepat } \\
\text { - Berfikir dulu dan menjawab } \\
\text { dengan benar } \\
\text { - Berfikir dulu tapi menjawab } \\
\text { tidak tepat } \\
\text { - Tidak menjawab }\end{array}$ & $\begin{array}{l}8 \\
6 \\
4 \\
2\end{array}$ & $\begin{array}{l}\text { Sangat Tepat } \\
\text { Tepat } \\
\text { Cukup } \\
\text { Tidak Tepat } \\
\text { Sangat Tidak Tepat }\end{array}$ \\
\hline
\end{tabular}


Jurnal Pendidikan Akuntansi Indonesia, Vol. XI, No. 1, Tahun 2013

Dian Paramita Candra Astika \& Isroah

Halaman $29-49$

\begin{tabular}{|c|c|c|c|}
\hline $\begin{array}{l}\text { 2. Kerapian } \\
\text { dalam } \\
\text { menulis dan } \\
\text { membuat } \\
\text { sistematika } \\
\text { penyusunan } \\
\text { laporan }\end{array}$ & $\begin{array}{l}\text { - Membuat laporan keuangan } \\
\text { dengan sangat rapi dan } \\
\text { sistematis } \\
\text { - Membuat laporan keuangan } \\
\text { dengan rapi dan sistematis } \\
\text { - Membuat laporan keuangan } \\
\text { cukup rapi dan sistematis } \\
\text { - Membuat laporan tidak rapi } \\
\text { dan sistematis } \\
\text { - Membuat laporan tidak rapi } \\
\text { dan tidak sistematis }\end{array}$ & 10 & $\begin{array}{l}\text { Sangat Tepat } \\
\text { Tepat } \\
\text { Cukup } \\
\text { Tidak Tepat } \\
\text { Sangat Tidak Tepat }\end{array}$ \\
\hline $\begin{array}{l}\text { 3. Kebenaran } \\
\text { dalam } \\
\text { pengisian } \\
\text { akun-akun ke } \\
\text { dalam } \\
\text { masing- } \\
\text { masing } \\
\text { laporan }\end{array}$ & $\begin{array}{l}\text { - Benar dan tepat menempatkan } \\
\text { akun-akun dalam laporan } \\
\text { - Benar menempatkan akun- } \\
\text { akun dalam laporan } \\
\text { - Cukup benar dan tepat } \\
\text { menempatkan akun dalam } \\
\text { laporan keuangan } \\
\text { - Salah dan kurang tepat } \\
\text { menempatkan akun dalam } \\
\text { laporan. } \\
\text { - Salah dan sangat tidak tepat } \\
\text { menempatkan akun dalam } \\
\text { laporan keuangan. }\end{array}$ & 10 & $\begin{array}{l}\text { Sangat Tepat } \\
\text { Tepat } \\
\text { Cukup } \\
\text { Tidak Tepat } \\
\text { Sangat Tidak Tepat }\end{array}$ \\
\hline
\end{tabular}

c) Catatan Lapangan

Catatan Lapangan berupa formulir yang digunakan untuk mencatat segala bentuk

Keaktifan Belajar Siswa selama proses pembelajaran berlangsung yang berkaita

dengan penggunaan Model Active Learning Teknik Learning Starts With A Questionmulai dari siklus I sampai siklus II.

\section{Prosedur Penelitian}

a) Siklus I

1) Perencanaan

Dalam penelitian ini, pada tahap perencanaan peneliti melakukan persiapan berkaitan dengan semua hal yang dibutuhkan dalam PTK yaitu:

(a) Identifikasi dan analisis permasalahan yang dihadapi guru dan siswa selama proses pembelajaran melalui studi pendahuluan.

(b) Menyusun perangkat pembelajaran yang terdiri dari skenario proses pembelajaran, membuat Rencana Pelaksanaan Pembelajaran (RPP), materi ajar, serta menyiapkan media pembelajaran yang sesuai. 
(c) Menyusun alat perekam data yang berupa soal pretest dan posttest hasil

belajar, lembar observasi keaktifan siswa dan catatan lapangan.

(d) Merencanakan pembelajaran teori dan praktik sesuai dengan rencana dengan menerapkan metode belajar peer teaching.

2) Tindakan

Pada tahap ini tindakan yang dilaksanakan sesuai yang sudah direncanakan pada tahan Perencanaan Tindakan 1, yaitu:

(a) Melakukan refleksi dan analisis terhadap permasalahanpermasalahan temuan observasi awal. Hasil refleksi dan analisis ini kemudian digunakan sebagai acuan menyusun perangkat pembelajaran dan alat perekam data.

(b) Melaksanakan pembelajaran yang sesuai dengan skenario proses pembelajaran, rencana pelaksanaan pembelajaran, materi ajar, serta menyiapkan media pembelajaran yang sesuai.

(c) Menggunakan alat perekam data yang berupa soal pretest dan posttest, lembar observasi aktivitas belajar siswa dan lembar catatan lapangan dalam pelaksanaan pembelajaran.

(d) Melaksanakan pembelajaran materi sistem penerangan sesuai rencana pelaksanaan pembelajaran dan menerapkan metode belajar peer teaching.

3) Pengamatan

Kegiatan observasi dilakukan bersamaan dengan pelaksanaan tindakan. Penelitian ini bersifat kolaborasi dan partisipatif, sehingga dalam tahap observasi pengamatan dilakukan oleh peneliti dibantu guru mata pelajaran dan observer yang mengamati kegiatan siswa.

4) Refleksi

Dalam penelitian ini, tahap refleksi dilakukan oleh peneliti terhadap hasil pengamatan dibantu oleh guru sebagai pelaku tindakan. Hasil dari tahap ini kemudian digunakan oleh peneliti sebagai dasar bagi tindakan selanjutnya.

b) Siklus II

Berdasarkan analisis dan refleksi siklus 1, maka akan direncanakan tindakan siklus 2. Kegiatan pada siklus 2 hampir sama dengan siklus 1 , tetapi tindakan pada siklus 2 diperbaiki berdasarkan hasil refleksi pada siklus 1 dan pada siklus 2 lebih ditekankan pada diskusi kelompok dan presentasi di depan kelas untuk menilai keaktifan siswa. Kegiatan yang dilakukan pada siklus 2 bertujuan untuk memperbaiki pelaksanaan pembelajaran pada siklus 1 agar mencapai indikator keberhasilan.

\section{Teknik Analisis Data}

a) Analisis Data Kualitatif

(1) Reduksi Data

Data yang diperoleh dari penelitian ini awalnya berupa bahan mentah yang berasal dari hasil observasi dan catatan lapangan. Datadata tersebut akan direduksi untuk memperoleh informasi yang lebih bermakna sesuai dengan tujuan penelitian. 
(2) Penyajian Data

Penyajian data yang umum digunakan dalam penelitian kualitatif adalah dengan teks yang bersifat naratif.

(3) Penarikan Kesimpulan

Penarikan kesimpulan disajikan kedalam sebuah pernyataan untuk menjawab rumusan masalah yang diajukan pada awal penelitian.

b) Analisis Data Deskriptif Kuantitatif dengan Persentase

Data yang diperoleh dari lembar observasi yang berbentuk rating scale selanjutnya dilakukan analisis untuk mengetahui persentase skor Keaktifan Belajar Siswa. Untuk menganalisis dilakukan langkah-langkah sebagai berikut:

(1) Menentukan kriteria pemberian skor terhadap masing-masing diskriptor pada setiap aspek keaktifan siswa dan hasil belajar yang digunakan.

(2) Menjumlahkan skor untuk masing-masing aspek keaktifan dan hasil belajar.

(3) Menghitung skor keaktifan dan hasil belajar pada setiap aspek dengan rumus:

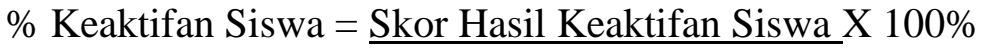

Skor Maksimum

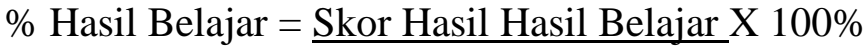

Skor Maksimum

(4) Terhadap data tes hasil belajar siswa, dilakukan analisis dengan menentukan nilai rata-rata nilai test, peningkatan (gain) dari pretest dan posttest pada siklus 1 dan 2 serta jumlah siswa yang tuntas belajar pada siklus 1 dan 2, kemudian membandingkan hasil yang diperoleh pada siklus 1 dan 2

\section{Indikator Keberhasilan}

Kriteria keberhasilan tindakan adalah apabila setelah pengimplementasian Metode Belajar Peer Teaching, terjadi Peningkatan Keaktifan Belajar Siswa dan Hasil Belajar Akuntansi. Dilihat dari segi proses, pembelajaran dikatakan berhasil dan berkualitas jika seluruh atau sebagian besar $(75 \%)$ siswa terlibat secara aktif (Mulyasa, 2006: 256) dan siswa dapat menunjukkan peningkatan Hasil Belajar Akuntansi dari hasil posttest yang sudah memenuhi Kreteria Ketuntasan Minimal (KKM) yaitu 70.

\section{Hasil Penelitian Dan Pembahasan}

1. Laporan Siklus 1

a) Perencanaan (planning)

Pada siklus ini dilakukan 1 kali pertemuan yaitu 4 x 45 menit Materi yang disampaikan pada siklus I adalah menyusun laporan keuangan perusahaan jasa. Meteri pokok yang diajarkan pada pertemuan ini adalah, hubungan laporan keuangan dengan buku besar, macam-macam unsur laporan keuangan dan bentuk-bentuk laporan keuangan perusahaan jasa. Siklus 1 memerlukan berbagai perangkat pembelajaran dan alat perekam data antara lain: 
(1) Rencana Pelaksanaan Pembelajaran (RPP) yang berisi pedoman guru dalam melaksanakan pembelajaran

(2) Bahan ajar siswa untuk membantu siswa mempelajari materi yang sedang dipelajari

(3) Lembar observasi keaktifan siswa untuk mengetahui aktivitas

(4) dan keaktifan siswa dalam kelas saat mengikuti proses belajar dan mengajar.Lembar untuk menilai ranah afektif dan psikomotor siswa yang dapat diamati saat pembelajaran berlangsung.

(5) Alat evaluasi berupa soal tes untuk mengetahui perkembangan prestasi belajar siswa setelah mengikuti proses belajar dan mengajar dengan menggunakan metode belajar peer teaching.

Strategi pembelajaran menggunakan metode belajar peer teaching, yang berorientasi pada peran aktif siswa dalam proses belajar dan mengajar. Peer teaching pada siklus 1 akan dilaksanakan dikelas dengan membagi siswa dalam kelompok dengan tutor 6 orang yang telah dipilih guru dan peneliti sebelumnya berdasarkan hasil ulangan harian dan keaktifan siswa di kelas yang akan dijadikan tutor. Pada saat pembelajaran berlangsung siswa akan dibagi menjadi 6 kelompok dengan jumlah anggota 5-6 siswa yang akan belajar bersama dengan keenam tutor yang telah dipilih untuk membantu temannya belajar.

b) Pelaksanaan (acting)

Pada pelaksanaan tindakan siklus 1 hanya terdiri dari satu pertemuan dengan materi pokok yaitu "Mengidentifikasi MacamMacam dan Bentuk Laporan Keuangan" yang akan dijadikan pokok bahasan dalam berdiskusi oleh siswa menggunakan motode belajar peer teaching. Selama pelaksanaan tindakan, observer dan peneliti melaksanakan observasi dengan mencatat berbagai proses yang terjadi pada saat proses belajar dan mengajar berlangsung sesuai dengan poin-poin yang termuat dalam lembar observasi keaktifan siswa dan lembar penilaian hasil belajar ranah afektif dan psikomotor. Peneliti dibantu oleh 3 observer yang membantu peneliti dalam melakukan pengamatan, karena peneliti dan guru akan berkolaborasi dalam mengajar. Peneliti menggantikan posisi guru pelajaran untuk mengajar.

Pada siklus 1 pelaksanaan proses belajar dan mengajar mata pelajaran kompetensi kejuruan akuntansi dengan kompetensi dasar menyusun laporan keuangan khususnya laporan keuangan pada perusahaan jasa dilaksanakan di kelas. Pembelajaran pada siklus 1 dilaksanakan pada tanggal 7 November 2012 dimulai pada pukul 7.15-10.15 WIB selama 180 menit (4x45 menit). Adapun pelaksanan tindakan siklus 1 dapat dijabarkan sebagai berikut ini.

(1) Kegiatan Pendahuluan

Guru memulai pembelajaran dengan mengucapkan salam terlebih dahulu dan mengkondisikan kelas. Kemudian guru membuka pelajaran dengan memberi salam dan berdoa. Guru mempresensi kehadiran siswa dan memotivasi kesiapan belajar siswa. Guru menjelaskan kepada siswa bahwa selama seminggu 
ini guru dan peneliti akan berkolaborasi dalam mengajar dan melaksanakan metode belajar peer teaching (teman sebaya) dan menyampaikan proses belajar dan mengajar menggunakan metode belajar peer teaching.

(2) Kegiatan Inti

Kegiatan inti pembelajaran pertama dilakukan mengulas materi sebelumnya dan kemudian guru mengadakan pretest selama 30 menit yang diikuti oleh 34 orang siswa, dari keseluruhan siswa kelas X Ak 2 adalah 35 orang.

Pada kegiatan inti guru menyampaikan materi pelajaran dengan menjelaskan sekilas tentang laporan keuangan diantaranya hubungan laporan keuangan dengan buku besar, macam-macam unsur laporan keungan, bentuk-bentuk laporan keuangan, dan menjelaskan peralatan dan bahan yang dibutuhkan untuk membuat laporan keuangan. Guru memberi beberapa pertanyaan terkait meteri yang akan disampaikan, kemudian menunjuk siswa secara acak untuk mencoba menjawab pertanyaan tersebut guna menarik kosentrasi siswa ke dalam proses belajar mengajar yang sedang berlangsung. Jawaban yang disampaikan oleh beberapa siswa kemudian dijadikan bahan diskusi sejenak agar siswa terfokus pada proses belajar dan mengajar.

Setelah 20 menit proses belajar berlangsung, guru menunjuk 6 orang siswa yang paling aktif dan dinilai memiliki kompentensi yang cukup baik berdasarkan hasil ulangan harian, untuk maju ke depan kelas dan memberikannya kesempatan untuk mempelajari materi tentang laporan keuangan melalui materi yang disiapkan dengan bantuan guru. Siswa yang lain kemudian dibagi menjadi 6 kelompok dengan cara berhitung saat keenam tutor sedang mempelajari materi yang diberikan. Setelah terbentuk keenam kelompok, siswa kemudian mendiskusikan materi yang menjadi permasalahan dan kemudian akan dipresentasikan sesuai dengan kelompoknya masing-masing. Sepuluh menit berikutnya posisi guru digantikan oleh ke-6 siswa yang terpilih untuk menyampaikan materi dengan panduan buku materi yang ada kepada masing-masing kelompok yang telah terbentuk. Tutor beserta masing-masing kelompok mendiskusikan materi yang akan dipresentasikan. Siswa yang belum paham tentang materi menyusun laporan keuangan bisa langsung menanyakannya kepada tutor mereka masing-masing.

(3) Kegiatan Penutup

Kegiatan terakhir pada pelaksanaan siklus I adalah pelaksanaan posttest. test ini dilaksanakan selama 30 menit. Setelah selesai mengerjakan posttest, siswa memperhatikan penyampaian kompetensi yang akan dipelajari pada pertemuan berikutnya, kemudian kegiatan pembelajaran diakhiri oleh doa bersama. 
c) Pengamatan (observing)

Hasil pengamatan yang dilakukan oleh observer dan peneliti memperoleh beberapa kesimpulan, yaitu:

(1) Keaktifan Siswa

Pada siklus I, siswa masih bingung dengan metode belajar yang diterapkan, beberapa siswa masih ada yang cenderung diam dan belum aktif dalam pembelajaran, begitu juga dengan tutor yang masih belum percaya diri menjelaskan materi kepada teman sekelompoknya. Setelah diadakan diskusi secara kelompok dan presentasi kelompok membuat para siswa lebih termotivasi dan lebih aktif.

Tabel 5 . Keaktifan Siswa Siklus I

\begin{tabular}{|l|l|c|}
\hline No & \multicolumn{1}{|c|}{ Aspek keaktifan siswa yang dinilai } & Persentase \\
\hline 1 & Mencatat materi akuntansi & $79,41 \%$ \\
\hline 2 & Membuat rencana belajar & $29,41 \%$ \\
\hline 3 & $\begin{array}{l}\text { Membantu kesulitan teman sekelompok } \\
\text { dalam menguasai materi pelajaran }\end{array}$ & $82,35 \%$ \\
\hline 4 & Mengemukakan pendapat dalam diskusi & $69,12 \%$ \\
\hline 5 & Mempresentasikan hasil diskusi & $80,88 \%$ \\
\hline 6 & $\begin{array}{l}\text { Siswa bertanya saat pembelajaran maupun } \\
\text { diskusi tentang materi }\end{array}$ & $67,64 \%$ \\
\hline 7 & $\begin{array}{l}\text { Siswa menjawab pertanyaan yang diberikan } \\
\text { guru maupun teman saat diskusi }\end{array}$ & $67,64 \%$ \\
\hline 8 & Mengerjakan tugas akuntansi & $88,23 \%$ \\
\hline 9 & Berpartisipasi dalam tugas kelompok & $80,88 \%$ \\
\hline 10 & $\begin{array}{l}\text { Memberikan kesimpulan di akhir } \\
\text { pertemuan }\end{array}$ & $32,35 \%$ \\
\hline \multicolumn{2}{|c|}{ JUMLAH } & $\mathbf{6 7 7 , 9 1 \%}$ \\
\hline \multicolumn{2}{|c|}{ RATA-RATA } \\
\hline
\end{tabular}

(2) Hasil belajar

(Sumber dari pengolahan data pada lampiran 2: 167)

Siklus 1 diawali dengan melaksanakan pretest sebelum melakukan proses belajar dan mengajar dan pada akhir siklus dilaksanakan posttest untuk mengetahui perkembangan hasil belajar siswa secara kognitif setelah penerapan metode belajar peer teaching. Hasil belajar yang diamati oleh peneliti dan observer tidak hanya pada ranah kognitif saja, namun peneliti juga berusaha mengamati hasil belajar siswa pada ranah afektif dan psikomotor yang diamati pada lembar observasi dengan beberapa aspek yang dinilai. Hasil belajar ranah kognitif dinilai dari tes yang diberikan kepada siswa untuk menilai kemampuannya dalam memahami materi yang disampaikan.

Pada pretest siklus I nilai yang dicapai masih rendah yaitu dengan rata-rata nilai kelas 63,20, hal itu dapat dilihat dari nilai terendah yang dicapai adalah 40, sedangkan nilai tertinggi adalah 77, sedangkan siswa yang dapat memenuhi ketentuan kelulusan yaitu nilai 70 hanya mencapai 32,35\%. 
Setelah penerapan metode belajar peer teaching pada proses belajar mengajar akuntansi, hasil belajar siswa mengalami peningkatan. Pada posttest yang dilakukan setelah proses pembelajaran siklus I yaitu semua siswa peserta tes dapat memenuhi Kreteria Ketuntasan Minimal dengan nilai 70, dengan nilai rata-rata kelas 80,88 . Jika dilakukan perbandingan pada rata-rata nilai pretest dan posttest maka terjadi peningkatan rata-rata kelas sebesar 17,68 yaitu dari 63,20 menjadi 80,88.

Tabel 6. Penilaian Hasil Belajar Ranah Afektif Siklus 1

\begin{tabular}{|l|c|}
\hline \multicolumn{1}{|c|}{ Aspek yang dinilai } & Persentase \\
\hline $\begin{array}{l}\text { 6. Berpakaian rapi sesuai dengan } \\
\text { ketentuan sekolah }\end{array}$ & $76,32 \%$ \\
\hline 7. Datang sekolah tepat waktu & $76,91 \%$ \\
\hline $\begin{array}{l}\text { 8. Memberikan saran dalam diskusi } \\
\text { dengan sopan }\end{array}$ & $75,88 \%$ \\
\hline $\begin{array}{l}\text { 9. Membawa peralatan dan kelengkapan } \\
\text { belajar yang ditugaskan guru }\end{array}$ & $80,73 \%$ \\
\hline $\begin{array}{c}\text { 10. Mengumpulkan semua tugas yang } \\
\text { diberikan tepat waktu }\end{array}$ & $\mathbf{7 7 , 2 0 \%}$ \\
\hline JUMLAH & $\mathbf{3 8 7 , 0 4 \%}$ \\
\hline RATA-RATA & $\mathbf{7 7 , 4 1 \%}$ \\
\hline
\end{tabular}

Penilaian hasil belajar selanjutnya adalah dari ranah psikomotor yang ditunjukan pada tabel 7 berikut:

Tabel 7. Penilaian Hasil Belajar Ranah Psikomotor Siklus 1

\begin{tabular}{|c|c|}
\hline Aspek Penilaian & Persentase \\
\hline 4. Respon jika diberi pertanyaan & $56,47 \%$ \\
\hline $\begin{array}{l}\text { 5. Kerapian dalam menulis dan membuat } \\
\text { sistematika penyusunan laporan }\end{array}$ & $71,17 \%$ \\
\hline $\begin{array}{l}\text { 6. Kebenaran dalam pengisian akun-akun ke } \\
\text { dalam masing-masing laporan }\end{array}$ & $54,70 \%$ \\
\hline JUMLAH & $182,34 \%$ \\
\hline RATA-RATA & $\begin{array}{c}182,34 \% / 3= \\
60,78 \%\end{array}$ \\
\hline
\end{tabular}

d) Refleksi (reflecting)

Pembelajaran pada siklus 1 difokuskan pada keaktifan siswa dalam aspek yaitu membuat rencana belajar, aspek mengemukakan pendapat dalam diskusi, aspek bertanya saat pembelajaran maupun diskusi tentang materi, aspek menjawab pertanyaan yang diberikan guru maupun teman saat diskusi, dan aspek memberikan kesimpulan di akhir pertemuan.

Berdasarkan hasil observasi keaktifan siswa dan test hasil belajar dalam proses belajar dan mengajar mata pelajaran Akuntansi, dapat diambil beberapa kesimpulan dari pelaksanaan siklus I, yaitu:

a) Siswa masih pasif dalam mengemukakan pendapat dalam berkelompok dan hanya beberapa siswa yang aktif sehingga 
proses pelaksanaan diskusi kurang bisa membawa siswa aktif untuk berbicara.

b) Aspek yang belum mencapai indikator keberhasilan diantaranya: membuat rencana belajar yang hanya mencapai $29,41 \%$, aspek mengemukakan pendapat dalam diskusi hanya mencapai 69,12, aspek siswa bertanya saat pembelajaran maupun diskusi tentang materi hanya mencapai $67,64 \%$, aspek siswa menjawab pertanyaan yang diberikan guru maupun teman saat diskusi hanya mencapai $67,64 \%$, dan aspek memberikan kesimpulan di akhir pertemuan hanya mencapai $32,35 \%$.

c) Hasil belajar mengalami peningkatan dari hasil pretest yang dilakukan di awal pertemuan dan posttest yang dilakukan pada akhir pertemuan.

d) Totur teman sebaya yang dipilih beberapa masih kurang bisa berbicara dengan lugas dan kurang percaya diri, sehingga penjelasannya kurang bisa ditangkap siswa lain dan timbul banyak permintaan untuk mengulangi penjelasan yang disampaikannya.

Berdasarkan kesimpulan siklus 1 di atas, maka tujuan kegiatan pembelajaran ini belum tercapai secara maksimal, karena keaktifan siswa masih banyak yang belum muncul pada pembelajaran sehingga kegiatan pembelajaran ini perlu dilanjutkan pada siklus berikutnya, dengan mengkaji ulang rancangan pembelajaran yang dibuat oleh peneliti sesuai dengan permasalahan yang didapatkan pada siklus 1 .

2. Laporan Siklus 2

a) Perencanaan (planning)

Pada siklus ini dilakukan 2 kali tatap muka yaitu 4x 45 menit dan 1 kali tatap muka yaitu 1 x 45 menit. Materi yang disampaikan pada siklus II adalah kelanjutan dari materi menyusun laporan keuangan perusahaan jasa. Meteri pokok yang diajarkan pada pertemuan ini adalah mengikhtisarkan data dalam Laporan Laba/Rugi, Laporan Perubahan Modal dan Neraca serta mengidentifikasikan laporan tambahan lainnya.

b) Pelaksanaan (acting)

Pada siklus 2 merupakan pelaksanaan proses belajar dan mengajar mata pelajaran kompetensi kejuruan akuntansi dengan kompetensi dasar menyusun laporan keuangan khususnya laporan keuangan pada perusahaan jasa dilaksanakan di kelas. Pembelajaran pada siklus kedua dilaksanakan pada tanggal 8 November 2012 dimulai pada pukul 10.30-12.00 WIB dilanjutkan pukul 12.20-13.50 selama 180 menit ( $4 \times 45$ menit). Adapun pelaksanan tindakan siklus 2 dapat dijabarkan sebagai berikut ini:

(1) Kegiatan Pendahuluan

Pada siklus 2 pelaksanaan proses belajar dan mengajar mata pelajaran Akuntansi kelas X Ak 2 dilakukan 2 kali pertemuan yaitu selama 4 jam pelajaran $(4 x 45 m e n i t)$ dan 1 jam pelajaran 
(1x45menit). Kegiatan pembelajaran diikuti oleh 34 orang siswa, dari keseluruhan siswa kelas X Ak 2 adalah 35 orang.

Awal pelajaran guru membuka pelajaran dengan berdoa, absensi dan menyampaikan tujuan pembelajaran yang terkait dengan matei ajar yang disampaikan. Guru menyampaikan bahwa metode belajar yang akan diterapkan sama seperti pertemuan sebelumnya yaitu dengan menggunakan metode belajar peer teaching yang merupakan kelanjutan siklus 1 . Perbedaan siklus 1 dan siklus 2 adalah pada siklus 1 materi yag diberikan lebih banyak teori, sedangkan pada siklus 2 lebih cenderung ke praktik. Kegiatan awal yang dilakukan guru dan peneliti pada pertemuan pertama siklus kedua ini adalah melakukan pretest karena materi yang disampaikan pada siklus 2 ini lebih banyak ke praktik.

(2) Kegiatan Inti

Pada kegiatan inti guru memulai pelajaran dengan menyampaikan beberapa pertanyaan terkait dengan meteri yang akan disampaikan, kemudian menunjuk siswa secara acak untuk mencoba menjawab pertanyaan tersebut guna menarik kosentrasi siswa ke dalam proses belajar dan mengajar yang sedang berlangsung. Jawaban yang disampaikan oleh beberapa siswa kemudian dijadikan bahan diskusi sejenak agar siswa terfokus pada proses belajar dan mengajar.

Masing-masing kelompok kemudian menempatkan diri pada kelompoknya masing-masing untuk membahas materi yang dipresentasikan di kelas. Keenam tutor diberikan penguatan materi dan motivasi lebih agar mampu membantu belajar teman sekelompoknya lebih baik lagi dari pada sebelumnya. Tutor diminta agar lebih lugas dan percaya diri dalam menjawab pertanyaan temannya satu kelompok.

\section{(3) Kegiatan Penutup}

Peneliti menggumumkan kepada para siswa bahwa pertemuan selanjutkan disimpulkan dari materi kompetensi dasar menyusun laporan keuangan perusahaan jasa dan kemudian dilanjutkan dengan posttest kedua. Para siswa sangat antusias dan lebih bersemangat untuk belajar bersama dengan tutor mereka. Kemudian pelajaran diakhiri dengan berdoa.

Pada siklus 2 pertemuan kedua dilaksanakan pembelajran selama 1jam yaitu $1 \times 45$ menit untuk melaksanakan posttest yang ke2 yang dilaksanakan pada hari Sabtu, 10 November 2012 pukul 11.15-12.00 menjelang istirahat kedua, adapun pelaksanaan siklus 2 pada pertemuan kedua ini sebagai berikut:

(1) Kegiatan Pendahuluan

Kegiatan ini diawali dengan berdoa dan kemudian memotivasi siswa untuk melaksanakan posttest pada siklus 2, siswa sudah lebih siap dan antusias untuk mengikuti tes. Siswa sudah 
mempersiapkan segala peralatan yang dibutuhkan untuk melaksanakan tes.

(2) Kegiatan Inti

Kegiatan inti pada pertemuan kedua siklus pertama ini adalah siswa mengerjakan posttest dengan waktu 40 menit menjelang istirahat. Siswa terlihat lebih mudah dan bersemangat mengerjakan tes yang diberikan.

(3) Kegiatan Penutup

Peneliti menutup pelajaran dengan doa dan memberikan motivasi kepada siswa agar terus rajin belajar dan saling membantu apabila terdapat kesulitan dalam memahami materi pelajaran.

c) Pengamatan (observing)

Hasil pengamatan yang dilakukan oleh observer dan guru mata pelajaran akuntansi memperoleh beberapa kesimpulan, yaitu:

(1) Keaktifan Siswa

Siswa sudah mampu menyesuaikan cara belajarnya dengan metode belajar peer teaching yang diterapkan pada siklus 2 . Keaktifan siswa meningkat dari siklus 1, siswa menunjukkan peningkatan setelah mulai penerapan metode belajar peer teaching.

Tabel 8 . Keaktifan Siswa pada Siklus 2

\begin{tabular}{|l|l|c|}
\hline No & \multicolumn{1}{|c|}{ Aspek keaktifan siswa yang dinilai } & Persentase \\
\hline 1 & Mencatat materi akuntansi & $92,65 \%$ \\
\hline 2 & Membuat rencana belajar & $76,47 \%$ \\
\hline 3 & $\begin{array}{l}\text { Membantu kesulitan teman sekelompok } \\
\text { dalam menguasai materi pelajaran }\end{array}$ & $92,65 \%$ \\
\hline 4 & Mengemukakan pendapat dalam diskusi & $95,59 \%$ \\
\hline 5 & Mempresentasikan hasil diskusi & $91,18 \%$ \\
\hline 6 & $\begin{array}{l}\text { Siswa bertanya saat pembelajaran maupun } \\
\text { diskusi tentang materi }\end{array}$ & $89,70 \%$ \\
\hline 7 & $\begin{array}{l}\text { Siswa menjawab pertanyaan yang diberikan } \\
\text { guru maupun teman saat diskusi }\end{array}$ & $76,47 \%$ \\
\hline 8 & \begin{tabular}{l} 
Mengerjakan tugas akuntansi \\
\hline 9
\end{tabular} & Berpartisipasi dalam tugas kelompok \\
\hline 10 & $\begin{array}{l}\text { Memberikan kesimpulan di akhir } \\
\text { pertemuan }\end{array}$ & $95,59 \%$ \\
\hline \multicolumn{2}{|c|}{ JUMLAH } & $76,47 \%$ \\
\hline \multicolumn{2}{|c|}{ RATA-RATA } & $\mathbf{8 8 5 , 1 8 \%}$ \\
\hline
\end{tabular}

(2) Hasil Belajar

Setelah penerapan metode belajar peer teaching pada proses belajar mengajar akuntansi, hasil belajar siswa mengalami peningkatan. Pada posttest yang dilakukan setelah proses pembelajaran siklus 1 yaitu semua siswa peserta tes dapat memenuhi Kreteria Ketuntasan Minimal dengan nilai 70, dengan nilai rata-rata kelas 90,65, mengalami peningkatan dari pretest dan posttest siklus 1 . Jika dilakukan perbandingan pada 
rata-rata nilai pretest dan posttest pada siklus 2 maka terjadi peningkatan rata-rata kelas sebesar 22,41 yaitu dari 68,24 menjadi 90,65. Begitu juga apabila dibandingkan hasilnya dengan posttest siklus 1 terjadi peningkatan sebesar 9,77 yaitu dari 80,88 menjadi 90,65.

Tabel 9. Penilaian Hasil Belajar Ranah Afektif Siklus 2

\begin{tabular}{|l|c|}
\hline \multicolumn{1}{|c|}{ Aspek yang dinilai } & Persentase \\
\hline $\begin{array}{l}\text { 1. Berpakaian rapi sesuai dengan } \\
\text { ketentuan sekolah }\end{array}$ & $86,76 \%$ \\
\hline 2. Datang sekolah tepat waktu & $87,35 \%$ \\
\hline $\begin{array}{l}\text { 3. Memberikan saran dalam diskusi } \\
\text { dengan sopan }\end{array}$ & $86,91 \%$ \\
\hline $\begin{array}{l}\text { 4. Membawa peralatan dan kelengkapan } \\
\text { belajar yang ditugaskan guru }\end{array}$ & $90,44 \%$ \\
\hline $\begin{array}{l}\text { 5. Mengumpulkan semua tugas yang } \\
\text { diberikan tepat waktu }\end{array}$ & $88,09 \%$ \\
\hline JUMLAH & $\mathbf{4 3 9 , 5 5 \%}$ \\
\hline RATA-RATA & $\mathbf{8 7 , 9 1 \%}$ \\
\hline
\end{tabular}

Tabel 10. Penilaian Hasil Belajar Ranah Psikomotor Siklus 2

\begin{tabular}{|c|c|}
\hline \multicolumn{1}{|c|}{ Aspek Penilaian } & Persentase \\
\hline 1. Respon jika diberi pertanyaan & $82,94 \%$ \\
\hline $\begin{array}{c}\text { 2. Kerapian dalam menulis dan membuat } \\
\text { sistematika penyusunan laporan }\end{array}$ & $87,06 \%$ \\
\hline $\begin{array}{c}\text { 3. Kebenaran dalam pengisian akun-akun ke } \\
\text { dalam masing-masing laporan }\end{array}$ & $85,88 \%$ \\
\hline JUMLAH & $\mathbf{2 5 5 , 8 8 \%}$ \\
\hline RATA-RATA & $\mathbf{8 5 , 2 9 \%}$ \\
\hline
\end{tabular}

d) Refleksi (reflecting)

Berdasarkan hasil observasi keaktifan siswa dan hasil belajar siswa dalam proses belajar dan mengajar pada kompetensi menyusun laporan keuangan perusahaan jasa, dapat diambil beberapa kesimpulan dari pelaksanaan siklus 2, yaitu:

(1) Aspek yang belum mencapai indikator keberhasilan pada siklus 1 sudah mengalami peningkatan dan telah mencapai indikator keberhasilan diantaranya aspek : membuat rencana belajar sudah mencapai $76,47 \%$, aspek mengemukakan pendapat dalam diskusi sudah mencapai $95,59 \%$, aspek siswa bertanya saat pembelajaran maupun diskusi tentang materi sudah mencapai 89,70\%, aspek siswa menjawab pertanyaan yang diberikan guru maupun teman saat diskusi mencapai $76,47 \%$, dan aspek memberikan kesimpulan di akhir pertemuan sudah mencapai $76,47 \%$. Begitu juga dengan aspek keaktifan yang lainnya sudah mengalami peningkatan dari siklus sebelumnya 
(2) Aktivitas negative dapat dikurangi karena kelas dibagi kedalam kelompok

kecil sehingga perhatian siswa terfokus pada diskusi yang diselenggarakan dikelompoknya. Suasana kelas terkesan lebih tenang jika dibandingkan dengan siklus 1 , siswa hanya melakukan diskusi dengan tutor di dalam kelompoknya, sehingga semua siswa dapat ikut serta berperan aktif pada kegiatan diskusi yang berlangsung dan meminimalisir kemungkinan siswa yang membicarakan hal lain diluar materi.

(3) Hasil belajar kognitif mengalami peningkatan dari hasil pretest yang dilakukan di awal pertemuan dan posttest yang dilakukan pada akhir pertemuan. Hasil belajar ranah afektif dan psikomotor yang juga sudah mengalami peningkatan.

(4) Totur teman sebaya yang dipilih lebih lugas berbicara dan menyampaikan penjelasannya, sehingga tanya jawab yang muncul pada diskusi dapat diatur dengan baik oleh tutor.

\section{Pembahasan}

Dari penelitian yang dilakukan dengan metode belajar peer teaching dalam Kompetensi Keahlian Akuntansi pada siswa kelas $\mathrm{X}$ Ak. 2 SMK Negeri 1 Yogyakarata baik pada siklus 1 maupun siklus 2 siswa menunjukan keaktifan belajar yang mendukung proses pembelajaran. Hal ini ditunjukan dari skor keaktifan siswa pada setiap siklus dilihat dari masing-masing aspek yang diamati. Pada siklus 2 terjadi peningkatan keaktifan siswa dibandingkan siklus 1, keaktifan siswa apabila dirata-rata mengalami peningkatan sebesar $20,73 \%$ yang pada siklus 1 mencapai $67,79 \%$ menjadi $88,52 \%$.

Hasil belajar yang diperoleh siswa mengalami peningkatan dari siklus 1 ke siklus 2 . Ketuntasan belajar pada pretest siklus 1 yang mencapai KKM 70 hanya 32,35\% sedangkan pada posttest siklus 1 mencapai $91,18 \%$, sedangkan ketuntasan belajar pada pretest siklus 2 adalah 47,22\%, namun pada posttest siklus 2 ketuntasan belajar mencapai $100 \%$.

Hasil belajar ranah afektif juga mengalami peningkatan dari hasil pengamatan pada siklus 1 dan siklus 2 dari masing-masing aspek yang diamati, sehingga menunjukan peningkatan rata-rata sebesar $10,50 \%$ dari siklus $177,41 \%$ menjadi $87,91 \%$. Aspek yang diamati pada hasil belajar ranah afektif ini terdapat 5 aspek dalam lembar observasi.

Persentase peningkatan rata-rata hasil belajar ranah psikomotor dari siklus 1 ke siklus 2 adalah sebesar $24,51 \%$ yaitu dari rata-rata hasil belajar psikomotor pada siklus $160,78 \%$ meningkat pada siklus 2 menjadi $85,29 \%$.

\section{Penutup}

1. Simpulan
a) Keaktifan Siswa 
Dari hasil pengamatan keaktifan siswa apabila dirata-rata juga mengalami peningkatan sebesar $20,73 \%$ yang pada siklus 1 mencapai $67,79 \%$ menjadi $88,52 \%$.

b) Hasil Belajar

1) Hasil Belajar dilihat dari Aspek Kognitif

Hasil belajar yang diperoleh siswa mengalami peningkatan dari siklus 1 ke siklus 2 . Ketuntasan belajar pada pretest siklus 1 yang mencapai KKM 70 hanya 32,35\% sedangkan pada posttest siklus 1 mencapai $91,18 \%$, sedangkan ketuntasan belajar pada pretest siklus 2 adalah 47,22\%, namun pada posttest siklus 2 ketuntasan belajar mencapai $100 \%$.

2) Hasil Belajar dilihat dari Aspek Afektif

Hasil belajar ranah afektif juga mengalami peningkatan dari hasil pengamatan pada siklus 1 dan siklus 2 dari masing-masing aspek yang diamati, sehingga menunjukan peningkatan rata-rata sebesar 10,50\% dari siklus $177,41 \%$ menjadi 87,91\%.

3) Hasil Belajar dilihat dari Aspek Psikomotor

Persentase peningkatan rata-rata hasil belajar ranah psikomotor dari siklus 1 ke siklus 2 adalah sebesar $24,51 \%$ yaitu dari ratarata hasil belajar psikomotor pada siklus $160,78 \%$ meningkat pada siklus 2 menjadi 85,29\%.

2. Keterbatasan Penelitian

Penelitian yang dilakukan di kelas X Akuntansi 2 SMK Negeri 1 Yogyakarta mengalami berbagai keterbatasan antara lain:

a. Skor ketercapaian indikator keaktifan siswa yang didapat dari hasil observasi mencerminkan skor ketercapaian keaktifan siswa secara klasikal, sehingga terdapat beberapa skor siswa yang tinggi dapat menutupi skor siswa lain yang rendah.

b. Waktu penelitian berdekatan dengan pelaksanaan Ujian akhir sekolah, dan jumlah minggu efektif kegiatan belajar mengajar yang sedikit, menyebabkan peneliti hanya dapat melaksanakan penelitian sebanyak 2 siklus. Hal ini menyebabkan penelitian menjadi kurang optimal walaupun hasil yang diperoleh sudah mencapai indikator keberhasilan.

3. Saran

a. Kepada siswa, agar selalu aktif dalam kegiatan pembelajaran metode belajar peer teaching untuk melatih dan meningkatkan hasil belajar baik membantu memecahkan permasalahan belajar teman maupun permasalahan belajar individu.

b. Kepada para guru mata pelajaran Akuntansi, agar mencoba menerapkan metode belajar peer teaching sebagai alternatif untuk meningkatkan keaktifan siswa dan hasil belajar siswa.

c. Kepada peneliti lain, agar menjadikan hasil penelitian ini sebagai bahan referensi untuk melakukan penelitian lebih lanjut mengenai pelaksanaan metode belajar peer teaching sehingga diperoleh hasil penelitian yang lebih maksimal lagi. 


\section{E. Daftar Pustaka}

Anas Sudjino. (2007). Pengantar Evaluasi Pendidikan. Jakarta: PT Grafindo Persada

Ari Satriana. (2008). Upaya Meningkatkan Ketuntasan Belajar Melalui Pembelajaran Remidial dengan Model Peer Teaching Pada Mata Pelajaran Fisika di MAN Yogyakarta I. Skripsi. Yogyakarta: FMPA UNY.

Dimyati dan Mudjiono. (2006). Belajar dan Mengajar. Bandung: Rineka Cipta . . (2009). Belajar dan Pembelajaran. Bandung: Rineka Cipta.

Depdiknas. (2003). Undang-undang Republik Indonesia Nomor 20 Tentang Sistem Pendidikan Nasioal. Jakarta: Depdiknas RI.

Endang Mulyatiningsih. (2001). Metode Penelitian Terapan Bidang Pendidikan. Bandung: Alfabeta.

Hendi Somantri. (2006). Memahami Akuntansi SMK Seri A Bidang Keahlian Bisnis dan Manajemen program Keahlian Akuntansi. Bandung: Amirco.

I Putu Berty Maharyana. (2009). Upaya Meningkatkan Prestasi Belajar dengan Menerapkan Metode Belajar Peer Teaching pada Mata Diklat Perawatan dan Perbaikan Kelistrikan Otomotif di SMK Tamansiswa Yogyakarta. Skripsi. Yogyakarta: FT UNY.

I Wayan Deta Aftawyana Angra. (2012). Upaya Meningkatkan Kaaktifan Belajar Siswa dengan Menerapkan Metode Belajar Peer Teaching Pada Pelajaran Menerapkan Algoritma Pemograman Tingkat Dasar di SMK N 2 Depok Yogyakarta Kelas X TKJ B. Skripsi. Yogyakarta: FT UNY.

Maritis Yamin. (2007). Kiat Membelajarkan Siswa. Jakarta: Gaung Persada Press.

- (2008). Desain Pembelajaran Berbasis Tingkat Satuan Pendidikan. Jakarta: Gaung Persada Press.

Muhibbin Syah. (2008). Psikologi Pendidikan Pendekatan Baru. Bandung: Remaja Rosdakarya.

Mulyasa. (2007). Kurikulum Tingkat Satuan Pendidikan. Bandung: Remaja Rosdakarya.

Moh.Uzer Usman. (2004). Menjadi Guru Profesional. Bandung: Remaja Rosdakarya.

Nana Sudjana. (2006). Dasar-Dasar proses Belajar Mengajar. Bandung: Remaja Rosdakarya. . (2002). Penilaian Hasil Proses Belajar Mengajar. Bandung: Remaja Rosdakarya.

Nelly Masnila. (2010). Bahan Ajar Pengantar Akuntansi 1. Palembang: Politeknik Negeri Sriwijaya Palembang.

Oemar Hamalik. (2006). Proses Belajar Mengajar. Jakarta: Bumi Aksara. 
Jurnal Pendidikan Akuntansi Indonesia, Vol. XI, No. 1, Tahun 2013

Dian Paramita Candra Astika \& Isroah

Halaman 29 - 49

Rochiati Wiriaatmadja. (2009). Metode Penelitian Tindakan Kelas. Bandung: Remaja Rosdakarya.

Sardiman. (2011). Interaksi dan Motivasi Belajar-Mengajar. Jakarta: Rajawali Pers.

Slameto. (2003). Belajar dan Faktor-Faktor yang Mempengaruhiny. Jakarta: Rineka Cipta.

Suharsimi Arikunto, dkk. (2008). Penelitian Tindakan Kelas. Jakarta: Bumi Aksara.

. (2009). Dasar-Dasar Evaluasi Pendidikan. Jakarta: Bumi Aksara. . (2010). Prosedur Penelitian Suatu Pendekatan Praktik. Jakarta: Bumi Aksara.

Sugiyono. (2009). Metode Penelitian Pendidikan: Pendekatan Kuantitatif, Kualitatif, dan R\&D. Bandung: Alfabeta.

Suntusia. (2008). Pengaruh Penerapan Metode Peer Teaching dalam Pembelajaran Fisika terhadap Prestasi Belajar Siswa pada Kurikulum Tingkat Satuan Pendidikan Pokok Bahasan Gelombang Elektromagnetik Kelas X di SMA Muhammadiyah Bondowoso 2007/2008. Skripsi. Yogyakarta: FMIPA UNY.

S. Nasution. (2011). Berbagai Pendekatan dalam Progres Belajar dan Mengajar. Jakarta: Bumi Aksara.

Yatim Riyanto. (2009). Paradigma Baru Pembelajaran:Sebagai Referensi bagi Pendidik dalam Implementasi Pembelajaran yang Efektif dan Berkualitas. Jakarta: Kencana. 